\title{
Massa Protein dan Lemak Daging Dada pada Ayam Broiler yang Mengkonsumsi Ransum Mengandung Bawang Hitam (Black garlic)
}

\author{
Berliana, Nelwida dan Nurhayati* \\ ${ }^{*}$ Fakultas Peternakan, Universitas Jambi, Mendalo Indah Jambi 36361
}

\begin{abstract}
ABSTRAK
Penelitian ini bertujuan untuk mengevaluasi penggunaan bawang hitam atau black garlic dalam ransum terhadap massa protein dan massa lemak daging ayam broiler. Penelitian ini dilakukan di Farm dan Laboratorium Terpadu Fakultas Peternakan Universitas Jambi menggunakan 100 ekor ayam pedaging umur sehari Day Old Chick (DOC) strain New Lohman MB 202. Penelitian berlangsung sampai ayam berumur 35 hari. Percobaan dilakukan menggunakan Rancangan Acak Lengkap (RAL) dengan 5 perlakuan dan 4 ulangan dimana setiap ulangan berisi 5 ekor ayam. Perlakuan yang diberikan yaitu $\mathrm{P} 0=100 \%$ ransum komersial, $\mathrm{P} 1=\mathrm{P} 0+2 \%$ black garlic, $\mathrm{P} 2=\mathrm{P} 0+3 \%$ black garlic, $\mathrm{P} 3=\mathrm{P} 0+4 \%$ black garlic dan $\mathrm{P} 4=\mathrm{P} 0+5 \%$ black garlic . Peubah yang diamati adalah konsumsi ransum, konsumsi protein, persentase daging dada tanpa tulang dan kulit, massa protein dan massa lemak daging bagian dada. Data diolah menggunakan analisis ragam dan pengaruh yang nyata dilanjutkan dengan uji jarak berganda Duncan. Hasil analisis ragam menunjukkan bahwa penambahan black garlic sampai 5\% berpengaruh tidak nyata $(\mathrm{P}>0.05)$ terhadap konsumsi ransum, konsumsi protein, massa protein dan massa lemak daging. Dari penelitian ini dapat disimpulkan bahwa penambahan black garlic sampai 5\% dalam ransum tidak dapat meningkatkan massa protein dan menurunkan massa lemak daging dada ayam broiler.
\end{abstract}

Kata kunci: Black garlic, Broiler, Massa protein, Lemak daging

\section{Breast Meat Mass Protein and Fat of Broiler Chicken Consumed Diet Containing Black Garlic}

\begin{abstract}
The purpose of the study was to evaluate the effect of black garlic powder in broiler chickens ration on protein and fat meat mass. Experiment was conducted in farm and integrated laboratory in the Faculty of Animal Science, University of Jambi based on the completely randomized design (RAL), consisted of 5 treatments and 4 replications with 5 chicks each. Chickens were kept for 5 weeks in colony cages. The treatments were; $P 0=$ Commercial diet, $P 1=P 0+2 \%$ black garlic powder, $P 2=$ $P 0+3 \%$ black garlic powder, $P 3=P O+4 \%$ black garlic powder and $P 4=P 0+5 \%$ black garlic powder. Parameters measured were feed consumption, protein consumption, protein and fat of breast meat mass. Data were statically analyzed by analysis of variance and tested by Duncan's Multiple Range Test test when the treatment had significant effect. The result of this study found that additon black garlic powder to broiler diet until 5\% had no significant effect $(P>0.05)$ on feed consumption, protein consumption, mass protein and fat meat. It is concluded that addition of black garlic up to $5 \%$ into the broiler chicken ration might not increase mass protein and decrease fat meat yet.
\end{abstract}

Keywords: Black garlic, Broiler, Mass protein, Fat meat

\section{PENDAHULUAN}

Semakin meningkatnya pengetahuan masyarakat akan pentingnya kesehatan, menyebabkan permintaan akan daging yang berkualitas tinggi dan aman untuk dikonsumsi juga semakin meningkat. Kualitas daging didefinisikan sebagai istilah yang menggambarkan semua karakteristik daging termasuk didalamnya adalah kandungan nutrisi (Anadon, 2002).

Kandungan nutrisi pada daging diukur dari kandungan air, protein, lemak, vitamin, mineral dan sedikit karbohidrat (Praseno dan Yuniwarti, 2000). Kandungan protein daging sangat ditentukan oleh deposisi protein dalam daging dimana deposisi protein dalam daging sangat ditentukan oleh konsumsi protein dan keseimbangan asam amino dalam ransum

*Penulis Korespondensi: Nurhayati

Alamat: Jl. Raya Jambi - Ma. Bulian KM 15 Mendalo Indah Jambi 36361 Indonesia

E-mail: nurhayati_agus@unja.ac.id
(Suthama et al., 2010). Proses deposisi protein dan asam-asam amino dalam daging sangat dipengaruhi oleh asupan protein, sedangkan asupan protein sangat ditentukan oleh konsumsi ransum (Gultom, 2014). Besarnya deposisi protein dalam daging dapat dilihat dari massa protein daging, yang merupakan indikator adanya selisih antara sintesis dan degradasi protein dalam tubuh atau dengan kata lain massa protein daging merupakan indikator untuk melihat baik atau buruknya deposisi protein di dalam tubuh.

Suthama (2003) menyatakan bahwa deposisi protein secara lebih spesifik dipengaruhi oleh dua proses yang bertentangan yaitu sintesis dan degradasi. Hal ini dibuktikan oleh Mirnawati et al. (2013) yang melaporkan bahwa massa protein daging pada ayam broiler yang diberi ransum dengan kandungan protein ransum sebesar $22,01 \%$ menghasilkan massa protein daging sebesar 109,9 gram, sedangkan ransum dengan kandungan protein sebesar $19,15 \%$ hanya menghasilkan massa protein daging sebesar 79,18 gram (Jamilah et al., 2013). Hal ini membuktikan bahwa 
ransum dengan kandungan protein rendah akan memiliki kandungan protein daging yang rendah pula (Kartikasari et al., 2001).

Menurut Ramli et al. (2002) untuk menghasilkan produk daging yang berkualitas atau bernilai gizi tinggi dapat dilakukan dengan pemberian bahan tambahan atau aditif pakan dalam ransum ternak, salah satunya adalah bawang putih (Allium sativum). Adibmoradi et al. (2006) melaporkan bahwa bawang putih nyata dapat meningkatkan tinggi villus dan kedalaman crypt (crypt depth), serta menurunkan ketebalan epitel dan jumlah sel goblet di duodenum, jejenum dan ileum unggas (Nusairat, 2007). Pertumbuhan tinggi villi usus halus berhubungan erat dengan potensi usus halus dalam menyerap zat-zat nutrisi. Semakin tinggi villi usus halus, semakin besar efektifitas penyerapan sari-sari makanan melalui epitel usus halus (Lenhard dan Mozes, 2003). Awad et al. (2008) melaporkan bahwa peningkatan tinggi vili pada usus halus ayam pedaging berkaitan erat dengan peningkatan fungsi pencernaan dan fungsi penyerapan karena meluasnya area absorpsi serta merupakan suatu ekspresi lancarnya sistem transportasi nutrisi ke seluruh tubuh.

Keadaan ini menjelaskan bahwa proses deposisi protein juga sangat didukung oleh kesehatan dan kemampuan usus sehingga proses pencernaan dan penyerapan protein juga dapat maksimal. Sejalan dengan pendapat Sukaryana et al. (2011) yang menyatakan bahwa kesehatan saluran pencernaan sangat mempengaruhi kecernaan. Kesehatan usus ditunjukkan oleh pertumbuhan vili, baik dalam hal ketinggian maupun kedalaman cripta (Yang et al., 2007; Awad et al., 2008). Hal ini akan diikuti oleh peningkatan kecernaan sejumlah nutrisi terutama protein pada ayam pedaging, Begley et al. (2006) juga menyatakan bahwa peningkatan pertumbuhan vili dapat memfasilitasi peningkatan penyerapan nutrisi, terutama protein. Sejalan dengan pendapat Yang et al. (2007) yang menyatakan bahwa pertumbuhan vili dapat menjadi faktor pendorong perbaikan kecernaan nutrisi, terutama protein, dan akhirnya akan meningkatkan pasokan protein ke daging. Didukung oleh Suprijatna et al. (2008) yang menyatakan bahwa usus halus merupakan organ utama tempat berlangsungnya pencernaan dan absorbsi produk pencernaan. Berbagai enzim yang masuk ke dalam saluran ini berfungsi mempercepat dan mengefisienkan pemecahan karbohidrat, protein dan lemak untuk mempermudah proses absorbsi.

Bawang putih juga dapat meningkatkan aktivitas enzim-enzim pankreas sehingga dapat memperbaiki penyerapan nutrisi (Ramakhrisna et al., 2003). Ali et al. (2016) juga melaporkan bahwa penambahan tepung bawang putih dalam ransum dapat meningkatkan persentase protein kasar daging. Suplementasi bawang putih $2.0 \%$ dapat memperbaiki kualitas daging ayam broiler umur 42 hari (Yalcin et al., 2006). Hasil penelitian Hidajati (2005) menunjukkan bahwa suplementasi bawang putih dosis $2 \mathrm{mg} / \mathrm{ekor} / \mathrm{hari}$ dapat menurunkan kadar lemak daging ayam pedaging.
Menurut Jaya (1997) bahwa bawang putih dapat digunakan untuk menghasilkan produk spesifik seperti daging rendah lemak. Al-Batshan dan Hussein (1999) menyatakan bahwa penurunan kadar lemak daging ini sebagai akibat dari peningkatan konsumsi protein dan asam amino lysin. Sehingga dengan meningkatnya konsumsi protein secara nyata akan meningkatkan berat karkas, persentase karkas, dan persentase daging dada (breast meat), dan nyata menurunkan lemak abdomen (abdominal fat).

Bawang putih memiliki 33 komponen sulfur, 17 asam amino, beberapa enzim dan mineral. Komponen sulfur inilah yang memberikan bau khas dan berbagai efek obat dari bawang putih (Londhe et al., 2011). Alternatif yang dilakukan untuk menghilangkan sifat khas bawang putih tersebut adalah melalui pengolahan dengan perlakuan panas (heat treatment) yang mampu meningkatkan rasa dan menciptakan kualitas baru dari bawang putih tanpa menghilangkan komponen zat gizi bawang putih mentah yang dikenal dengan nama bawang hitam (black garlic).

Menurut Wang et al. (2010) dan Bae et al. (2014) black garlic merupakan bawang putih yang telah difermentasi selama lebih dari satu bulan dengan menggunakan oven pada suhu dan kelembaban tertentu, sehingga menghasilkan formulasi baru tanpa aroma khas bawang putih, tetapi khasiat dari black garlic melebihi bawang putih biasa. Lee et al. (2009) menyatakan bahwa selama proses pemanasan/ fermentasi, zat-zat yang terdapat di dalam bawang putih segar tidak akan rusak karena dibungkus dengan menggunakan alumunium foil. Menurut Berliana et al. (2018) black garlic dapat menurunkan kolesterol, trigeliserida dan LDL pada puyuh petelur. Aktivitas biologis black garlic nyata jauh lebih tinggi secara signifikan dibanding bawang putih segar (Sato et al., 2006).

Penelitian ini bertujuan untuk mengevaluasi penggunaan tepung bawang hitam (black garlic) dalam ransum terhadap massa protein dan massa lemak daging ayam broiler.

\section{MATERI DAN METODE}

\section{Tempat dan waktu}

Penelitian ini dilakukan di Farm Fakultas Peternakan Universitas Jambi dan analisa protein dan lemak daging dilakukan di Laboratorium Nutrisi dan Makanan Ternak Fakultas Peternakan Universitas Jambi.

\section{Materi Penelitian}

Materi yang digunakan adalah ayam broiler umur sehari (DOC) sebanyak 100 ekor dari strain New Lohman MB 202, tepung bawang hitam (black garlic), ransum komersial produksi Jafpa Comfeed serta kandang dan perlengkapannya. Ayam broiler dibagi dalam 5 perlakuan dengan 4 ulangan, setiap ulangan terdiri dari 5 ekor. Perlakuan yang diberikan adalah : $\mathrm{P} 0=100 \%$ ransum komersial $+0 \%$ black garlic 
$\mathrm{P} 1=100 \%$ ransum komersial $+2 \%$ black garlic

$\mathrm{P} 2=100 \%$ ransum komersial $+3 \%$ black garlic

$\mathrm{P} 3=100 \%$ ransum komersial $+4 \%$ black garlic

$\mathrm{P} 4=100 \%$ ransum komersial $+5 \%$ black garlic

\section{Peubah yang Diamati}

Peubah yang diamati dalam penelitian ini meliputi: konsumsi ransum, konsumsi protein, massa protein dan lemak daging dada broiler.

Konsumsi ransum dihitung berdasarkan selisih antara jumlah ransum disediakan dengan ransum sisa pada minggu yang sama, dinyatakan dalam gram/ekor/minggu. (Jaelani,2011);

Konsumsi Ransum= Ransum yang diberi (g) - Ransum Sisa $(g)$

Konsumsi protein dinyatakan dalam satuan gram, dihitung dengan rumus menurut Tillman et al. (2005) sebagai berikut:

Konsumsi protein $(\mathrm{g})=$ Konsumsi pakan $(\mathrm{g})$ x Kadar PK ransum $(\%)$

Massa protein dan lemak daging diperoleh dengan cara menganalisis sejumlah sampel yang diambil dari daging bagian dada tanpa kulit dan tulang pada umur 35 hari. Daging digiling halus kemudian dianalisis untuk memperoleh kadar protein dan lemak daging.

Massa protein daging= protein daging $(\%) \times$ bobot daging dada (tanpa kulit dan tulang) (Suthama, 2003).

Massa lemak daging diperoleh dengan menganalisis sejumlah sampel yang diambil dari daging dada dengan kulit dan tanpa tulang pada umur 35 hari.

Massa lemak daging= Lemak daging (\%) $\mathrm{x}$ bobot daging dada (dengan kulit tanpa tulang) (AOAC, 1990).

Data hasil penelitian dianalisis statistik menggunakan analisis ragam sesuai rancangan yang digunakan yaitu Rancangan Acak Lengkap (RAL). Pengaruh yang nyata antar perlakuan diuji lanjut menggunakan Uji jarak Berganda Duncan (Steel dan Torrie, 1993).

Tabel 1. Kandungan nutrisi ransum komersial dan black garlic

\begin{tabular}{lccc}
\hline \hline Kandungan & $\begin{array}{l}\text { Ransum } \\
\text { Nutrisi }\end{array}$ & $\begin{array}{c}\text { Ransum } \\
\text { Finisher }\end{array}$ & $\begin{array}{l}\text { Black } \\
\text { Garlic* }\end{array}$ \\
\hline Kadar air (\%) & 12,60 & 12,85 & 64,29 \\
Protein kasar (\%) & 22.52 & 19,73 & 16,78 \\
Lemak (\%) & 4,55 & 5,03 & 4,95 \\
Serat kasar (\%) & 4,65 & 5,71 & 1,50 \\
Abu (\%) & 7,05 & 7,43 & 5,91 \\
\hline ME (kkal/kg) & 3050 & 3150 & 1050 \\
\hline
\end{tabular}

Keterangan: *Hasil Analisis Laboratorium Terpadu Fakultas Peternakan Universitas Jambi (2019), *Berliana et al. (2018)

\section{HASIL DAN PEMBAHASAN}

Hasil pengamatan pada daging dada dengan penambahan bawang hitam dalam ransum terhadap konsumsi ransum, bobot daging, massa protein dan massa lemak daging dapat dilihat pada Tabel 4.

\section{Konsumsi Ransum}

Hasil analisis ragam menunjukkan bahwa penambahan black garlic sampai 5\% berpengaruh tidak nyata $(\mathrm{P}>0,05)$ terhadap konsumsi ransum ayam broiler, ini berarti bahwa penambahan black garlic sampai level 5\% dapat ditoleransi oleh ayam pedaging, ini diduga karena tidak terganggunya palatabilitas utamanya bau dan rasa tidak memberikan pengaruh pada konsumsi ransum ayam pedaging, kemungkinan lain adalah karena bentuk ransum dan black garlic yang diberikan dalam bentuk sama yaitu tepung. Black garlic tidak mempunyai rasa dan aroma yang kuat seperti bawang putih segar, ini disebabkan terjadi perubahan pada senyawa allin yang bertanggung jawab untuk aroma yang dirubah menjadi allicin (Choi et al., 2008).

Menurut Pourali et al. (2010) terjadi penurunan konsumsi ransum dengan semakin meningkatnya level pemberian tepung bawang putih disebabkan aroma bawang putih yang tajam. Didukung Javandel et al. (2008) yang melaporkan bahwa konsumsi ransum lebih tinggi pada penambahan tepung bawang putih yang lebih sedikit dibandingkan dengan level yang lebih tinggi. Wahyu (2004) juga menyatakan bahwa konsumsi ransum sangat dipengaruhi oleh palatabilitas ransum, bau, warna dan bentuk fisik ransum. Selain itu, karena penambahan black garlic dalam persentase yang sedikit sehingga tidak terlalu merubah komposisi nutrisi ransum terutama kandungan energi maupun proteinnya sehingga nilai konsumsi ransum menjadi sama. Sejalan dengan pendapat Wahyu (2004) yang menyatakan bahwa konsumsi ransum sangat dipengaruhi oleh kandungan energi dan protein dalam ransum, apabila kandungan energi dalam ransum melebihi kebutuhannya, maka unggas akan menurunkan konsumsi ransumnya.

\section{Persentase Bobot Daging Dada}

Hasil analisis ragam menunjukkan bahwa penambahan black garlic sampai taraf 5\% memberikan pengaruh yang tidak nyata $(\mathrm{P}>0,05)$ terhadap bobot relatif daging dada ayam broiler. Adanya peningkatan bobot relatif daging dada dengan semakin tingginya level penambahan black garlic dalam ransum dibanding dengan kontrol, ini diduga karena penambahan black garlic dapat meningkatkan penyerapan nutrisi sehingga mampu memperbaiki bobot relatif daging dada. Didukung Adibmoradi et al. (2006) yang menyatakan bahwa penambahan bawang putih nyata dapat meningkatkan tinggi villus dan kedalaman crypt (crypt depth) usus. Peningkatan tinggi vili pada usus berkaitan erat dengan peningkatan fungsi pencernaan dan fungsi penyerapan karena meluasnya area absorpsi serta merupakan suatu ekspresi lancarnya 
sistem transportasi nutrisi keseluruh tubuh (Awad et al., 2008).

Ibrahim (2008) menyatakan bahwa kemampuan pencernaan dan penyerapan zat-zat makanan dapat dipengaruhi oleh villi dan mikrovilli yang memperluas bidang penyerapan dan dipengaruhi juga oleh tinggi dan luas permukaan villi (Sugito, et al., 2007; Ibrahim 2008). Menurut Suharti (2004) bawang putih mampu memperlambat gerak peristaltik usus sehingga walaupun ransum yang dikonsumsi sedikit, tetapi penyerapannya meningkat sehingga menghasilkan berat badan yang lebih tinggi. Selain itu juga karena black garlic mengandung Allisin yang dapat menghilangkan bakteri patogen dan parasit-parasit pencernaan, sehingga ransum yang dikonsumsi dapat dicerna dan diserap dengan lebih baik.

Saravanan et al. (2010) menyatakan bahwa black garlic mempunyai kemampuan menghambat bakteri gram positif dan gram negatif dengan cara menghambat produksi RNA dan sintesis lipid, sehingga pertumbuhan dan perkembangan bakteri tidak akan terjadi. Lebih lanjut Dahlan dan Haqiqi (2012) menyatakan bahwa alliin dalam bawang putih atau allisin dalam black garlic adalah asam amino yang bermanfaat untuk pembentukan dan perkembangan sel, dan pada black garlic senyawa allicin yang terkandung dalam black garlic sampai lima kali lebih tinggi dibandingkan dengan bawang putih segar Choi et al. (2008). Selain itu alliin juga mengandung gurwich rays (sinar gurwich) yang berfungsi sebagai radiasi mitogenik yang dapat mempercepat dan memperbanyak pembentukan sel dalam tubuh sehingga berat ayam akan tercapai optimal (Dahlan dan Haqiqi, 2012).
Kisaran bobot relatif dada yang diperoleh dalam penelitian ini adalah 25,83-27,86\%, hasil ini lebih tinggi jika dibandingkan dengan Resnawati (2004) yang menyatakan bahwa persentase dada broiler berdasarkan berat karkas adalah 24,13\%-26,79\%, sedangkan menurut Pravita et al. (2016) bahwa persentase daging dada ayam broiler berdasarkan bobot karkas adalah $24,20 \%$.

\section{Massa Protein Daging}

Hasil analisis ragam menunjukkan bahwa penambahan black garlic hingga level 5\% dalam ransum berpengaruh tidak nyata $(\mathrm{P}>0,05)$ terhadap massa protein daging dada walaupun ada kecenderungan peningkatan massa protein daging dada dengan semakin tingginya level penambahan black garlic. Kadaan ini sejalan dengan konsumsi ransum yang juga semakin meningkat, ini menjelaskan bahwa dengan semakin meningkatnya konsumsi ransum akan semakin tinggi pula asupan protein. Sejalan dengan Suripta dan Astuti (2007) yang menyatakan bahwa konsumsi ransum berkorelasi positif dengan konsumsi protein dimana meningkat dan menurunnya konsumsi ransum seiring dengan menurun atau meningkatnya asupan protein, sedangkan asupan protein sangat berkaitan dengan tinggi rendahnya protein yang dideposisikan ke dalam daging. Deposisi protein daging dapat dinyatakan dalam bentuk massa protein daging yang juga sebagai indikator untuk menentukan tinggi rendahnya deposisi protein tubuh. Massa protein daging menunjukkan seberapa besar deposisi protein di dalam tubuh. Konsumsi protein yang tinggi diikuti dengan asupan protein yang tinggi, hal ini berarti

Tabel 2. Kandungan nutrisi ransum perlakuan fase starter

\begin{tabular}{lccccc}
\hline \hline Kandungan Nutrisi & P0 & P1 & P2 & P3 & P4 \\
\hline Kadar air (\%) & 12,6 & 13,88 & 14,52 & 15,17 & 15,81 \\
Protein kasar (\%) & 22,52 & 22,85 & 23,02 & 23,18 & 23,35 \\
Lemak (\%) & 4,55 & 4,65 & 4,70 & 4,75 & 4,80 \\
Serat kasar (\%) & 4,65 & 4,68 & 4,69 & 4,71 & 4,72 \\
Abu (\%) & 7,05 & 7,17 & 7,23 & 7,28 & 7,34 \\
\hline ME (kkal/kg) & 3050 & 3070,39 & 3080,58 & 3090,76 & 3100,95 \\
\hline
\end{tabular}

Keterangan: $\mathrm{P} 0=100 \%$ ransum komersial+0\% black garlic (kontrol), $\mathrm{P} 1=100 \%$ ransum komersial $+2 \%$ black garlic, $\mathrm{P} 2=$ $100 \%$ ransum komersial $+3 \%$ black garlic, $\mathrm{P} 3=100 \%$ ransum komersial $+4 \%$ black garlic, $\mathrm{P} 4=100 \%$ ransum komersial + $5 \%$ black garlic

Tabel 3. Kandungan nutrisi ransum perlakuan fase finisher

\begin{tabular}{lccccc}
\hline \hline Kandungan Nutrisi & P0 & P1 & P2 & P3 & P4 \\
\hline Kadar air (\%) & 12,85 & 14,13 & 14,77 & 15,42 & 16,06 \\
Protein kasar (\%) & 19,73 & 20,06 & 20,23 & 20,39 & 20,56 \\
Lemak (\%) & 5,03 & 5,13 & 5,18 & 5,23 & 5,27 \\
Serat kasar (\%) & 5,71 & 5,74 & 5,75 & 5,77 & 5,78 \\
Abu (\%) & 7,43 & 7,55 & 7,61 & 7,66 & 7,72 \\
\hline ME (kkal/kg) & 3150 & 3170,37 & 3180,55 & 3190,72 & 3200,90 \\
\hline
\end{tabular}

Keterangan: $\mathrm{P} 0=100 \%$ ransum komersial $+0 \%$ black garlic (kontrol), $\mathrm{P} 1=100 \%$ ransum komersial $+2 \%$ black garlic, $\mathrm{P} 2=100 \%$ ransum komersial $+3 \%$ black garlic, $\mathrm{P} 3=100 \%$ ransum komersial $+4 \%$ black garlic, $\mathrm{P} 4=100 \%$ ransum komersial $+5 \%$ black garlic 
semakin banyak protein yang dideposisikan menjadi daging. Deposisi protein merupakan banyaknya protein yang diserap dikurangi protein yang dimanfaatkan oleh tubuh dimana tingkat deposisi protein dipengaruhi oleh ketersediaan protein dan energi di dalam ransum, didukung oleh Gultom (2014) yang menyatakan bahwa konsumsi protein dipengaruhi oleh konsumsi ransum, sehingga konsumsi ransum yang baik berdampak pada konsumsi protein yang selanjutnya mempengaruhi asupan protein dan konsumsi protein yang tinggi akan mempengaruhi asupan protein yang dapat digunakan dalam proses deposisi protein dan asam-asam amino. Penambahan black garlic dalam ransum berarti menambah jumlah S-allylcysteine yang merupakan komponen utama belerang yang mengandung asam amino sebesar 5 - 6 kali lebih tinggi dibanding bawang putih segar (Bae et al., 2012).

Kemungkinan lain adalah karena black garlic mengandung senyawa allicin yang berfungsi sebagai antibakteri yang kuat sehingga dapat meningkatkan imunitas ayam broiler. Imunitas broiler yang baik menyebabkan protein tidak terlalu banyak yang dimanfaatkan untuk perbaikan jaringan dan pembentuk antibodi, sehingga protein yang dideposisi ke dalam daging menjadi tinggi. Massa protein daging meningkat jika protein yang disintesis melebihi protein yang didegradasi (Suthama, 1990).

Maharani et al. (2013) menunjukkan bukti bahwa semakin banyak protein yang diretensi, maka dapat memberikan kontribusi terhadap deposisi protein, sehingga menghasilkan massa protein daging yang tinggi pula. Didukung oleh Tillman et al. (2005) yang menyatakan bahwa faktor yang dapat meningkatkan massa protein daging adalah kecernaan protein, karena kecernaan protein diartikan sebagai jumlah asupan nutrien khususnya protein untuk proses sintesis protein. Maharani et al. (2013) menambahkan bahwa kecernaan protein dapat berpengaruh positif terhadap massa protein daging karena asupan substrat dalam bentuk protein sangat mendukung deposisi protein tubuh yang akhirnya mempercepat laju pertumbuhan. Menurut Suthama (2003) pertambahan bobot badan berkaitan erat dengan proses deposisi protein dalam daging. Jamilah et al. (2013) melaporkan bahwa massa protein daging pada ayam broiler yang dipelihara selama 6 minggu dengan kandungan protein ransum sebesar $19.15 \%$ menghasilkan massa protein daging sebesar 79,18 gram. Pada penelitian ini, penambahan black garlic hingga 5\% dalam ransum broiler yang dipelihara selama 5 minggu dengan kandungan protein sebesar $20,84 \%$ dapat menghasilkan rataan massa protein daging 99 gram.

\section{Massa Lemak Daging}

Hasil analisis ragam menunjukkan bahwa penambahan black garlic hingga level 5\% dalam ransum berpengaruh tidak nyata $(\mathrm{P}>0,05)$ terhadap massa lemak daging dada ayam broiler, walaupun terlihat adanya penurunan massa lemak dengan semakin meningkatnya level penggunaan black garlic dalam ransum. Hal ini diduga karena tingginya senyawa Allicin dan Scordinin atau senyawa bersulfur pada black garlic yang dapat mengikat garam empedu endogenus sehingga pembentukan emulsi lemak dalam bentuk miceless terhambat akibatnya penyerapan lemak dalam tubuh menurun. Syamsiah dan Tajudin (2004) menyatakan bawang putih mengandung unsur allicin yang didalamnya mengandung sulfur yang mampu meluruhkan lemak. Distribusi lemak dalam tubuh ayam menurun dengan adanya penambahan black garlic dalam ransum. Penurunan ini sebagai akibat dari peningkatan konsumsi protein dan asam amino lysin. Sebagaimana dilaporkan oleh Al-Batshan dan Hussein (1999), meningkatnya konsumsi protein secara nyata akan meningkatkan persentase daging dada dan nyata menurunkan lemak abdomen. Selain itu diduga juga bahwa penurunan akumulasi lemak tersebut juga disebabkan senyawa saponin dapat mengikat garamgaram empedu endogenus (endogenus bile cholesterol). Rendahnya persentase lemak memberikan indikasi bahwa pertambahan bobot daging dada dalam penelitian ini karena lebih tingginya deposisi protein dibanding lemak. Massa lemak daging mempunyai hubungan negatif dengan massa protein daging, sehingga penurunan massa lemak diikuti peningkatan massa protein daging, begitu pula sebaliknya. Menurut Hartono et al. (2013), lemak daging berkorelasi negatif terhadap protein daging.

Penurunan massa lemak pada daging ayam, juga terkait dengan kemampuan allisin yang tinggi dalam black garlic yang dapat menghambat fungsi enzimenzim yang terlibat dalam sintesis lemak sehingga dapat mempengaruhi proses metabolisme lemak. Sejalan dengan pen-dapat Yeh dan Liu (2001) dan Chowdhury et al. (2002) melaporkan bahwa komponen allisin dalam bawang putih dapat menghambat sintesis

Tabel 4. Pengaruh penambahan bawang hitam dalam ransum terhadap konsumsi ransum, bobot daging, massa protein dan massa lemak

\begin{tabular}{ccccc}
\hline \hline \multirow{2}{*}{ Perlakuan } & \multicolumn{3}{c}{ Peubah } \\
\cline { 2 - 5 } & $\begin{array}{c}\text { Konsumsi Ransum } \\
(\mathrm{g} / \text { /ekor/mgg) }\end{array}$ & $\begin{array}{c}\text { Bobot Daging Dada } \\
(\%)\end{array}$ & $\begin{array}{c}\text { Massa Protein Daging } \\
(\mathrm{g})\end{array}$ & Massa Lemak Daging (g) \\
\hline P0 & $524,33 \pm 8,87$ & $25,83 \pm 0,89$ & $85,08 \pm 3,35$ & $12,35 \pm 0,93$ \\
P1 & $517,49 \pm 8,29$ & $27,03 \pm 2,76$ & $88,45 \pm 2,79$ & $11,28 \pm 0,75$ \\
P2 & $513,53 \pm 7,98$ & $27,34 \pm 1,72$ & $94,75 \pm 6,40$ & $10,88 \pm 1,08$ \\
P3 & $506,35 \pm 10,43$ & $27,86 \pm 1,11$ & $94,63 \pm 3,94$ & $10,01 \pm 1,24$ \\
P4 & $507,44 \pm 10,31$ & $27,57 \pm 0,47$ & $99,00 \pm 5,19$ & $9,4 \pm 1,19$ \\
\hline
\end{tabular}


asam lemak di hati, sehingga dapat menurunkan kadar lemak daging. Lemak daging berkorelasi negatif terhadap protein daging, Ini berarti penurunan massa lemak diikuti peningkatan massa protein daging, begitu pula sebaliknya (Hartono et al., 2013). Selain itu lemak juga berkolerasi positif dengan kolesterol, karena kolesterol merupakan bagian dari lemak (Botham dan Mayes, 2012). Semakin tinggi kandungan lemak dalam daging unggas semakin tinggi pula kandungan kolesterol daging dan sebaliknya (Ismoyanti dan Widyastuti, 2003). Menurut Ichikawa et al. (2002) dan Kim et al. (2011) bahwa ekstrak black garlic memiliki kemampuan menurunkan kolesterol dan lemak atau hipokolesterolemia dan hipolipidemik, sehingga dengan penambahan black garlic dalam ransum juga akan dapat menurunkan kadar lemak daging broiler. Menurut Berliana et al. (2018), penambahan black garlic 3\% dalam ransum dapat menurunkan lemak kuning telur puyuh.

\section{KESIMPULAN}

Berdasarkan hasil penelitian dapat disimpulkan bahwa penambahan black garlic sampai 5\% dalam ransum tidakdapat meningkatkan massa protein dan menurunkan massa lemak daging dada ayam broiler.

\section{SARAN}

Perlu upaya mengkombinasikan penggunaan black garlic dengan bahan lain yang dapat meningkatkan konsumsi ransum sehingga dapat meningkatkan asupan dan deposisi protein dalam daging ayam broiler.

\section{UCAPAN TERIMA KASIH}

Ucapan terima kasih disampaikan kepada pimpinan Fakultas Peternakan Universitas Jambi dan reviewer yang telah menyetujui untuk mendanai penelitian ini melalui Dana PNBP Fakultas Peternakan. Terima kasih juga disampaikan kepada mahasiswa Program Sarjana pada Program studi Peternakan Rizky, Panji dan Arisy yang sudah terlibat dalam penelitian, laboran dan tekhnisi kandang.

\section{DAFTAR PUSTAKA}

Adibmoradi, M., B. Navidshad, J. Seifdavati and M. Royan. 2006. Effect of dietary garlic meal on histological structure of small intestine in broiler chickens. Japan Poultry Science 43: 378-383.

Al-Batshan, H.A. and E.O.S. Hussein.1999. Performance and carcass composition of broiler under heat stress: The effect of dietary energy and protein. Asian-Austalian Journal Animal Science 2(6): 914-922.

Ali, M.S., M. Kamruzzaman and Z.H. Khandaker.
2016. Effects of feeding garlic powder on growth performance and meat quality of broiler. Bangladesh Journal Animal Science 45(2): 7983

Anadon, H.L.S. 2002. Biological, nutritional and processing factors affecting breast meat quality of broilers. Dissertation. Faculty of Virginia Polytechnic Institute and State University. Blacksburg. Virginia.

AOAC. 1990. Officials method of analysis. 13ed. Association of Official Analytical Chemist, Washington, DC.

Awad, W.A., K. Ghareeb, S. Nitsch, S. Pasteiner, S.Abdel-Raheem and J. Bohm. 2008. Effect of dietary inclusion of probiotic, prebiotic and synbiotic on intestinal glucose absorbtion of broiler chickens. Int. Journal Poultry Science 7(7): 686-691.

Bae. S.E, S.Y. Cho, Y.D. Won, S.H. Lee SH and H.J. Park. 2012. A comparative study of the different analytical methods for analysis of $\mathrm{S}$ allylcysteine in black garlic by HPLC. LWTFood Science Technology 46(2): 532-535.

Bae, S.E., S.Y. Cho, Y.D. Won, S.H. Lee and H.J. Park. 2014. Changes in S-Allyl Cysteine Contents And Phsicochemical Properties Of Black Garlic During Heat Treatment. LWT-Food Science And Technology 55(1): 397-402.

Begley, M., C. Hill and C.G.M. Gahan. 2006 Bile salt hydrolase activity in probiotics. Applied Environment Microbiology 72(3) 1729-1738. doi:10.1128/AEM.72.3

Berliana, S., Nurhayati and Nelwida. 2018. Penggunaan Tepung Bawang Putih (Allium sativum Linn) Hitam (TBH) Dalam Ransum Terhadap Kadar Kolesterol Darah dan Lemak Kuning Telur Puyuh (Coturnix-coturnix japonica). Laporan Penelitian. Fakultas Peternakan. Universitas Jambi. Jambi.

Botham, K.M. and P.A. Mayes. 2012. Pengangkutan dan Penyimpanan Lipid. In: Biokimia Harper. 27th ed. Penerbit Buku Kedokteran (EGC). Jakarta.

Choi, J.D., J.S. Lee, J.M. Kang, S.H. Cho, J.N. Sung and H.J. Shin. 2008. Physicochemical Characteristics of Black Garlic (Allium sativum L.). Journal of the Korean Society of Food Science and Nutrition 37(4): 465-471.

Chowdhurry, S.R., S.D. Chowdhurry and T.K. Smith. 2002. Effects of dietary garlic on cholesterol metabolism in laying hens. Poultry Science 81: 1856-1862.

Dahlan. M. dan S. Haqiqi. 2012. Pengaruh Tepung Bawang Putih (Allium Sativum) Terhadap Kematian (Mortalitas) dan Berat Badan Ayam Pedaging. Jurnal Ternak 3(2): 3-9

Gultom, S. M., R.D.H. Supratman and Abun. 2014. Pengaruh Imbangan Energi dan Protein Ransum terhadap Bobot Karkas dan Bobot Lemak 
Abdominal Ayam Broiler Umur 3-5 Minggu. Laporan Penelitian. Fakultas Peternakan Universitas Padjajaran. Bandung

Hartono, E., N. Iriyanti dan R.S.S. Santosa. 2013. Penggunaan pakan fungsional terhadap daya ikat air, susut masak, dan keempukan daging ayam broiler. Jurnal Ilmiah Peternakan 1(1) : 10-19.

Hidajati. N. 2005. Peran Bawang Putih (Allium sativum) dalam meningkatkan kualitas daging ayam pedaging. Media Kedokteran Hewan 21(1): 32-34.

Ibrahim, S. 2008. Hubungan ukuran-ukuran usus halus dengan berat badan broiler. Agripet. 8(2): 42-46.

Ichikawa, M., K. Ryu, J.Yoshida, N. Ide, S.Yoshida,T. Sasaoka and S.I. Sumi.2002. Antioxidant effects of tetrahydro- $\beta$-carboline derivatives identified in aged garlic extract. Bio Factors 16: 57-72.

Ismoyowati. and T. Widiyastuti. 2003. Kandungan lemak dan kolesterol daging bagian dada dan paha berbagai unggas lokal. Journal of Animal Production 5(2): 79-82.

Jaelani, A. 2011. Performans Ayam Pedaging yang diberi Enzim Beta Mannanase dalam Ransum yang Berbasis Bungkil Inti Sawit. Fakultas Peternakan. Universitas Islam Kalimantan. Kalimantan

Jamilah, N., N. Suthama and L.D. Mahfudz. 2013. performa produksi dan ketahanan tubuh broiler yang diberi pakan step down dengan penambahan asam sitrat sebagai acidifier. Jurnal Ilmu Ternak dan Veteriner 18(4): 251-257.

Javandel, F., B. Navidshad, J. Seifdavati, G.H. Pourrahi and S.Baniyaghoub. 2008. The favorite dosage of garlic meal as a feed additive in broiler chickens ratios. Pakistan Journal Biological Science 11: 1746-1749.

Jaya, I.N.S. 1997. Pengaruh Penambahan Bawang Putih (Allium sativum L,) dalam Pakan pada Kadar Kolesterol Ayam Broiler. Laporan Penelitian. Institut Pertanian Bogor. Bogor.

Kartikasari, Soeparno and Setiyono. 2001. Komposisi kimia dan studi asam lemak daging dada ayam broiler yang mendapat suplementasi metionin pada pakan berkadar protein rendah. Buletin Peternakan 25: 33-39.

Kim, I., J.Y. Kim, Y.J. Hwang, K.A. Hwang, A.S. Om, J.H. Kim and K.J. Cho. 2011. The beneficial effects of aged black garlic extract on obesity and hyperlipidemia in rats fed a high-fat diet. Journal of Medicinal Plants Research 5(14):3159-3168.

Lee, Y.M., O.C. Gweon, Y.J. Seo, J. Im, M.J. Kang, M.J. Kim and J.I. Kim. 2009.Antioxidant effect of garlic and aged black garlic in animal model of type 2 diabetes mellitus. Nutrition Research and Practice 3: 156-161.

Lenhardt, L. and S. Mozes. 2003. Morphological and functional changes of the small intestine in growth-stunted broilers. Acta Veterinaria Brno 72: 353-358.

Londhe, V.P., A.T. Gavasane, S.S. Nipate, D.D. Bandawane and P.D. Chaudhari. 2011. Role of Garlic (Allium Sativum) in Various Disease: An Overview. Journal of Pharmaceutical Reserch and Opinion 1(4): 129-134.

Maharani, P., N. Suthama and H.I. Wahyuni. 2013. Massa kalsium dan protein daging pada ayam arab petelur yang diberi ransum menggunakan Azolla microphylla. Animal Agriculture Journal 2(1): 18-27.

Mirnawati., B. Sukamto and V. D. Yunianto.2013. Kecernaan protein, retensi nitrogen dan massa protein daging ayam broiler yang diberi ransum daun murbei (Morus alba L.) yang difermentasi dengan cairan rumen. Jurnal Inovasi Teknologi Pendidikan 3(1): 25- 32.

Nusairat, B.M. 2007. Dietary supplementation of garlic (Allium Sativum): Influence on performance parameters, meat quality and humoral immune response in broiler chicks. Jordan University of Science and Technology. Irbid. Jordan.

Pourali, M., S.A. Mirghelenj and H. Kermanshahi. 2010. Effects of garlic powder on productive performance and immune response of broiler chickens challenged with Newcastle disease virus. Global Veterinaria 4(6): 616-621.

Praseno, K., and E.Y.W.Yuniwarti. 2000. Biologi Aves. Universitas Diponegoro Press. Semarang.

Pravita, N.P.W.N., I.G.N.G. Bidura and D.P.M.A. Candrawati. 2016. Persentase daging dada dan paha broiler yang diberi pakan mengandung ampas tahu terfermentasi dengan khamir Saccharomyces $s p$. sebagai inokulan probiotik. Journal of Tropical Animal Science 4(1): 184195.

Ramakrishna, R.R., K. Platel and K. Srinivasan. 2003.In vitro influence of spices and spiceactive principles on digestive enzymes of rat pancreas and small intestine. Naehrung 47:408-412.

Ramli, N., M.N. Rofiq and S. Akhadiarto. 2002. Pengaruh teh fermentasi kombucha sebagai feed aditif terhadap persentase karkas, lemak abdomen dan organ dalam ayam broiler. Prosiding Seminar Nasional Teknologi Peternakan dan Veteriner 28-29 September 2002. Balai Penelitian Ternak Ciawi, Bogor.

Resnawati, H. 2004. Bobot potongan karkas dan lemak abdomen ayam ras pedaging yang diberi ransum mengandung tepung cacing tanah (Lumbricus rubellus). Pros. Seminar Nasional Teknologi Peternakan dan Veteriner. Bogor, 4-5 Agustus 2004. Puslitbang Peternakan, Bogor.

Saravanan, P., V. Ranya, H. Sridhar, V Balamurugan, and S. Umantaheswari. 2010. Antibacterial Activity of Allium s L., on Pathogenic Bacterial Strain. Global Veterinaria. 4(5): 519-522. 
Sato, E., M. Kohno and Y. Niwano. 2006. Increased level of tetrahydro- $\beta$-carbokine derivatives in shortterm fermented garlic. Plant Food for Human Nutrition 61: 175-178.

Steel, R.G.D. and J.H. Torrie. 1993. Principles and Procedures of Statistics, A Biometrical Approach International Student Ed. McGrawHill.

Sugito, W. Manalu, D.A. Astuti, E. Handharyani dan Chairul., 2007. Morfometrik usus dan performan ayam broiler yang diberi cekaman panas dan ekstrak n-heksana kulit batang 'jaloh' (Salix tetrasperma Rozb). Media Peternakan 30:198-206

Suharti, S. 2004. Kajian antibakteri temulawak, jahe dan bawang putih terhadap bakteri Salmonella typhymurium serta pengaruh bawang putih terhadap performans dan respon imun ayam pedaging. Institut pertanian Bogor, Bogor.

Sukaryana, Y., U. Atmomarsono, V.D. Yunianto dan E. Supriyatna. 2011. Peningkatan nilai kecernaan protein kasar dan lemak kasar produk fermentasi campuran bungkil inti sawit dan dedak padi pada broiler. Jurnal Inovasi Teknologi Pendidikan 3: 167-172.

Suprijatna, E., U. Atmomarsono, dan R. Kartasudjana. 2008. Ilmu dasar ternak unggas. Penebar Swadaya. Jakarta.

Suripta, H. and P. Astuti. 2007. Pengaruh penggunaan minyak lemuru dan minyak sawit dalam ransum terhadap rasio asam lemak omega-3 dan omega6 dalam telur burung puyuh (Coturnix coturnix japonica). Journal of Indonesian Tropical Animal Agriculture 32 (1): 22-27.

Suthama, N. 1990. Mechanism of growth promotion induced by dietary thyroxine in broiler chickens. Kagoshima University.

Suthama, N. 2003. Metabolisme protein pada ayam kampung periode pertumbuhan yang diberi ransum memakai dedak padi fermentasi. Jurnal Pengembangan Peternakan Tropika. Ed. Spesial: 44-48.

Suthama, N., H.I. Wahyuni dan I. Mangisah. 2010. Laju pertumbuhan berdasarkan degradasi protein tubuh pada ayam kedu dipelihara ex situ. Prosiding Seminar Nasional Tentang Unggas Lokal ke-IV. Semarang, Indonesia. p. 138-146. Syamsiah, S. dan Tajudin. 2004. Khasiat dan Manfaat Bawang Putih Raja Antibiotik Alami. Agro Media Pustaka. Jakarta.

Tillman, A. D., H. Hartadi, S. Reksohadiprodjo, S. Prawirokusumo and S. Lebdosoekojo. 2005. Ilmu Makanan Ternak Dasar. Gadjah Mada University Press. Yogyakarta.

Wahju, J. 2004. Ilmu Nutrisi Unggas. Cet. ke-5. Gadjah Mada University Press. Yogyakarta.

Wang, D., Y.H. Feng, J. Liu., J.Z. Yan, M.R. Wang J.I. Sasaki and C.L. Lu. 2010. Black garlic extracts enhance the immune system. Medicine Aromatic Plant Science and Biotechnology 4: 37-40.

Yalçın, S., E.E. Onbaşılar, Z. Reisli and S. Yalçın. 2006. Effect of garlic powder on the performance, egg traits and blood parameters of laying hens. Journal of the Science of Food and Agriculture 86(9): 1336-1339.

Yang, Y., P.A. Iji and M. Choct. 2007. Effects of different dietary levels of mannan oligosaccharide on growth performance and gut Development of boiler chickens. AsianAustralian Journal of Animal Sciences 20(7): 1084-1091.

Yeh, Y.Y. and L. Liu. 2001. Cholesterol-lowering effects of garlic extract dan organosulfur compounds: human dan animal studies. The Journal of Nutrition 131: 989S-993S. 